\title{
Musca domestica acts as transport vector hosts
}

Ragaa Issa

\begin{abstract}
Background: Musca domestica is the most common flies all over the world. More than 100 pathogens may cause diseases in human and animals. Houseflies transmitted helminthic eggs, protozoa cysts and trophozoites, bacteria fungi, and virus by mechanical transmission through its vomits or excreta. Musca domestica lives closely with humans and domestic animals, and often found in areas of human activities such as restaurants, hospitals, food centers, food markets, fish markets, and slaughterhouses.

Material and methods: Fly samples were collected from human houses, poultry farms and cattle byres placed on the bottom of a wide-mouthed sterile glass and covered with sterile sheets of gauze on which the attracted flies were trapped. Isolation parasites from external surface and digestive tract of fly, also, bacterial, fungi, and virus were identified using morphological and biological characteristics.

Results: Houseflies transmitted many of helminthic eggs as E. vermicularis, S. stercoralis, T. trichiura and T. caracanis, Trichomonas, Diphyllobothriam, hymenolepis, taenia and Dipylidium species, and protozoa cysts and trophozoites as E. histolytica, Giardia lamblia, and some bacteria as E. coli, Shigella species and Salmonella. In addition to viral, fungal are also isolated. Control methods are used for suppression of housefly population. These methods included cultural, biological, and chemical.

Conclusion: The common housefly is a mechanical vector of transmission of pathogens including parasites, bacteria, fungi, and viruses. The combination of different methods for control and prevention or eradication of houseflies should be implemented to stop human or animal diseases. In high-risk areas health education, proper environmental sanitation, and personal hygiene are strongly advocated.
\end{abstract}

Keywords: Musca domestica, Vector, Pathogens, Insecticide, Parasites, Bacteria, Fungi, Virus

\section{Introduction}

Musca domestica is the most common flies all over the world. More than 100 pathogens may cause diseases in human and animals by housefly. These pathogens included infantile diarrhea, anthrax, cholera, ophthalmia, bacillary dysentery, typhoid, and tuberculosis. Also, houseflies transmitted many of helminthic eggs as E. vermicularis, S. stercoralis, T. trichiura and T. caracanis, Trichomonas, Diphyllobothriam, hymenolepis, taenia, and Dipylidium species. It may also transmit protozoa cysts and trophozoites as E. histolytica and Giardia lamblia (Adenusi and Adewoga 2013a). Some bacteria carried by housefly as E. coli, Shigella species, and Salmonella, in addition to viral

Correspondence: ragaaissa@hotmail.com

Parasitology Department, Research Institute of Ophthalmology, Giza, Egypt pathogens through its vomits or excreta. It acts as a mechanical vector for diseases transmission, i.e., contaminated water, unhygienic food handlers, and convalescent carriers.

Musca domestica consists of egg, larva, pupa then adult, housefly has one pair of membranous wings, compound reddish eyes tarsi fine segmented with four dark strips on thorax. Its mouthparts are of sponging type to soak up the liquid food. It can feed on solid food after changing them to liquid by spitting or vomiting on it to dissolve by salivary gland secretions (Onyenwe et al. 2016). Adults of housefly can feed on human food, excreta animal dung, sweat, garbage, and wet or decaying matter of pet waste because they have strong odor. Also, housefly feed on syrup, meat broth, milk, and all materials present in human settlement areas. They feed twice or thrice a day (Iqbal et al. 2014). 
Housefly larvae named maggots and have 0.3 in. in length. A female housefly lays $75-150$ eggs in each hatch, it may lay 4-6 hatches. Garbage and filthy food are the main breeding sites for houseflies (Yahaya et al. 2016). Adult housefly has a life span from 15 to 30 days. Eggs have 1-2 $\mathrm{mm}$ in length, white in color, and within a day, the eggs are hatched into larvae. Larvae or maggots is $3-9 \mathrm{~mm}$ long, whitish in color, have no legs, and they feed on dead or decaying organic materials as feces or garbage. After 14 to $36 \mathrm{~h}$, it reached to $8 \mathrm{~mm}$. in length with brown color. Finally, it converted to pupa which changes into an adult housefly through 5 days. They favor the warm climatic conditions. Musca domestica lives closely with humans and domestic animals, and often found in areas of human activities such as restaurants, hospitals, food centers, food markets, fish markets, and slaughterhouses (El-Sherbini and El-Sherbini 2011). Over 100 pathogens including bacteria, fungi, virus, and parasites are carried by $M$. domestica, and they depend on the area where is collected. Pathogens were more frequently isolated from the body surfaces of houseflies, especially from those captured from human habitations and animal farms (Awache and Farouk 2016). The quantity of pathogens present in the gut is usually higher than the quantity present on the body surfaces suggesting that feces and vomitus may also serve as a major route of transmission of pathogens (Adenusi and Adewoga 2013b).

\section{Transmission of diseases}

Housefly causes mechanical transmission of pathogens from one vertebrate host to another without amplification or development of the organism within the vector. Bacterial and fungi were the most frequently isolated pathogens, parasites and viruses were the least frequently isolated pathogens (Deakpe et al. 2018).

Bacterial pathogens lead to diseases like typhoid, cholera, salmonellosis, dysentery, polio, diarrhea, tuberculosis, anthrax, and eye inflammation; virus like Rota virus, viral hepatitis, and poliomyelitis (Onyenwe et al. 2016); and fungi (Hussein 2014). The parasitological pathogens as enteric protozoa as cyst and trophozoites or helminthic eggs (Entamoena histolytica, Isospora species, Sacrocystis species, Entamoeba coli, Toxoplasma gondii, Giardia species, Cryptosporidium parvum, Trichomonas species, Dipylidium species, Hymenolepis species, and Diphyllobothrium species). Also, nematodes like helminthic eggs as Toxocara spp., Trichiuris trichiura, Strongyliod stercoralis, Taenia species, Ancyclostoma caninum, Enterobius vermicularis and larvae of Harbonema which they transport on their feet and hairy legs (Motazedian et al. 2014).

\section{How are to recognize the pathogens which are carried by houseflies}

Fly samples were collected from human houses, poultry farms, and cattle byres placed on the bottom of wide-mouthed sterile glass and covered with sterile sheets of gauze on which the attracted flies were trapped. From each location, $1 \mathrm{~g}$ of flies was weighed, and on each sampling, time packed in aluminum foil, transferred to the laboratory in the least possible time (Nwangwu et al. 2013).

\section{Bacterial identification}

Bacterial isolation of pathogens, after $24 \mathrm{~h}$ of incubation, the cultured specimen were brought out and examined for growth. Resultant colonies were identified using morphological and biological characteristics of the colonies, namely, Gram reaction, colonial morphology, and catalase test (Fig. 1).

The catalase test is one of the three main tests used by microbiologists to identify species of bacteria. The catalase test is done by placing a drop of hydrogen peroxide on a microscope slide. An applicator stick is touched to the colony, and the tip is then smeared onto the hydrogen peroxide drop.

If the mixture produces bubbles or froth, the organism is said to be 'catalase-positive.'

Capillary tubes may also be used. A small sample of bacteria is collected at the end of the capillary tube, without blocking the tube, to avoid false-negative results. The opposite end is then dipped into hydrogen peroxide, which is drawn into the tube through capillary action, and turned upside down, so that the bacterial points downwards. The hand holding the tube is then tapped on the bench, moving the hydrogen peroxide down until it touches the bacteria. If bubbles form on contact, this indicates a positive catalase result. This test can detect catalase-positive bacteria at concentrations above about $10^{5}$ cells $/ \mathrm{mL}$, (Martin 2012) and is simple to use. The presence of catalase in bacterial cells depends on both the growth condition and the medium used to grow the cells. While the catalase test alone cannot identify a particular organism, it can aid identification when combined with other tests such as antibiotic resistance.

Viruses are described by Tysasmaya et al. 2016, The cell culture and PCR may be used for isolation of the viruses from housefly organs as Rotavirus and Seneca virus (as veterinary importance) whose natural hosts are

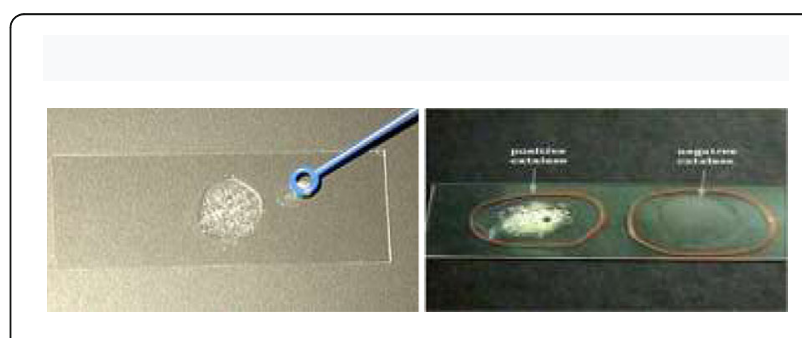

Positive catalase reaction

Fig. 1 Positive catalase reaction 
pigs and cows which causes a disease of pigs (PRRS) porcine reproductive and respiratory syndrome virus, also the blue-ear pig disease. Avian influenza virus and Newcastle disease virus which causes diseases in birds including poultry.

For fungal isolation, as Candida, Aspergillus, and Penicillium (important for human); Microsporum, Rhizopus, Scopularipsis, and Rhodotorula (important for veterinary); also, Curvalaria and Nigrospora (important for agricultural) (Awache and Farouk 2016).

The samples were treated according to (Nwangwu et al. 2013) as follows: each sample was triturated well in a sterile mortar with $10 \mathrm{ml}$ sterile normal saline solution to obtain a dilution of (1:10). After trituration, the sample was strained through a sterile funnel containing sterile gauze, the filtrate was collected aseptically in a test tube and subjected to mycological testing. The total fungal count of each sample was carried out according to the method advised by Motazedian et al. 2014 as follows: tenfold dilution was prepared from $1 \mathrm{ml}$ of the original filtrate $(1: 10)$ in a series of $9 \mathrm{ml}$ sterile saline to obtain different dilutions varying from $10^{2}$ up to $10^{10}$. Each dilution was inoculated in $10 \mathrm{ml}$ Sabouraud's dextrose agar plates. Double plates were made for each dilution. The inoculated plates were incubated at room temperature for 7 days. The average number of colonies was taken from the two plates of every dilution and multiplied to the reciprocal of the appropriate dilution to obtain the number of viable fungi per $1 \mathrm{~g}$ of flies. The identification of the isolated fungi was carried out using the methods described by Phoku et al. 2016, while the identification of yeasts followed the scheme of Awache and Farouk 2016. According to Deakpe et al. 2018 , the flies were placed into a plastic container and transported to the laboratory of parasitology to labeled specimen bottles carrying information like date, location, and type of sites. In the laboratory, the flies were demobilized by placing the fly traps and their contents inside a refrigerator or chest freezer to chill the flies within 20-40 min. The chilled flies were collected and picked to clean sterile centrifuge/test tubes to avoid contamination. The flies were washed thoroughly with $5 \mathrm{ml}$ of normal saline by vigorous shaking (hand shaken) to dislodge the parasites from the exoskeleton of the flies and their stages (Yahaya et al. 2016).

\section{Isolation parasites from external surface}

The suspension resulting from washing of the flies was used to isolate the parasites, and their stages attached to the bodies of the flies was transferred into a conical test tube and centrifuged at $3000 \mathrm{rpm}$ for 5 min then sediment was examined by $1 \%$ Lugol's iodin stain (Al-Aredhi 2015).

\section{Isolation parasites from the digestive tract of fly}

After washing, the digestive tract of each fly washed was dissected out under a microscope by needles and forceps, internal contents of each fly staining with modified Ziehl-Neelsen stain (Al-Aredhi 2015).

\section{Isolation and identification of the parasites}

There are two main major techniques in parasitology used for isolation of the parasites. They were flotation and sedimentation techniques (Yahaya et al. 2016; James 2019)

- Flotation technique:

In this technique, the zinc sulfate solution which has 1.18-1.20 specific gravity (nhydrometer) was used to recognize the parasites. The test tube half-filled with the suspension was of the bodies of the flies and was filled to the brim with zinc sulfate solution. A clean, grease-free coverslip was placed with care on top of the tube to avoid trapping of air bubbles. The coverslip carefully removed after $20 \mathrm{~min}$, by pulling it upwards and placed face downwards on a slide, and examined under microscope by $\times 10$ objective, then with drop of Lugol's iodine was dropped through the edge of the coverslip and examined with $40^{\mathrm{x}}$ objective to differentiate between the cysts of protozoa and eggs of helminths (Onyido et al., 2013).

- Sedimentation technique: This technique used for heavy trematode eggs, segments of cestodes which sank to the bottom of the test tube after was centrifuged at $2000 \mathrm{rpm}$ for $2 \mathrm{~min}$. The supernatant was decanted and about $1 \mathrm{~g}$ of the sediment places on a clean glass slide and covered with coverslip and examined under $\times 10$ objective of microscope then a drop of Lugol's iodine was dropped through the edge of the coverslip as above and it was reexamined under $\times 40$ objective lens to identify the cysts and eggs (Yahaya et al. 2016). For identification, the parasites were identified into various species and group using their shapes, sizes, and all signs of morphology.

\section{How to control the M. domestica}

There are three types of control methods for suppression of houseflies population. These methods included cultural, biological, and chemical control (Sarwar et al. 2014).

\section{Cultural control}

Using the gauze screen of windows doors, adjustment of the exhaust (blower) above the doors and also, installation of doors that mechanically open and close. Indoor conditions keeping houseflies away by electrocuting light traps and odor-baited traps are used. Moreover, the light and odor-baited traps are also involved in the killing of beneficial insects. The best cultural method is the disposal of 
garbage or any other organic matter properly which are breeding sites of housefly eggs. Most of $50 \%$ of houseflies in urban areas exist due to bad management of disposing of waste materials of household, hospital, and market waste material containers should be regularly disposed. At the disposal sites of garbage, the waste materials should be covered with a layer of about $15 \mathrm{~cm}$ soil or any other suitable inorganic material every week (Iqbal et al. 2014).

\section{Biological control}

Population of housefly may be suppressed by utilization of their natural enemies like entomic pathogenic fungi, nematodes, fire ants, predatory, beetles, mites, parasitic wasps (not harmful for human and animals), flies (hydrotaea aenescens wiedeman), and birds. Other biological control methods include the use of MdSGHV virus, this virus infects both sexes of flies, but the rate of infection in males is rapid. Young flies are not developed in females, it is because of the inhibition of yolk protein transcription and hexamerin production. As compared to healthy flies, infected flies show shorter life span and reduced rate of successful mating; bacterial (larvae of houseflies could be controlled by feeding Bacillus thuringensis to cattle and chickens breeding sites in a manner for release exotoxin (Lietze et al. 2010). New strains of bacteria have been discovered in different countries of the world including Korea, Egypt, and South Africa for housefly control due to the acidic conditions $(\mathrm{pH})$ of digestive system of flies or deficiency of receptors for endotoxin; fungi like Entomophthora muscae and E. schizophorae. The flies were killed within 4-6 days (Mwamburi et al. 2011). In temperate regions, the infection rate of houseflies with natural epizootics is more than $50 \%$ in the fall season. Recent 34 strains of fungi show lesser killing time of houseflies that is less than $24 \mathrm{~h}$; nematodes (population of housefly can be controlled by nematodes like Steinernematids and Hetrohabditids). It gives better results in the manure of cow when mixed with soil than when it is used in pig and poultry manure (Iqbal et al. 2014). Essential oils obtained from plant sources (the use of botanical oils, change in the behavior of houseflies like attraction, repellence, and toxicity on their contact to flies at different developmental stages have been reported. Essential oil possessing specific amounts of 1,8-cinesle, menthol, limonene, and pulegone shows effective toxicity to adult houseflies. The essential oils possess fumigant insecticide properties due to the presences of acetyle cholinesterase inhibition and octopaminergic action); and use if insects as predator, parasite, or parasitoid housefly (histerid beetles and macrochield mites eat up eggs and larvae of housefly population at large scale (Urzua et al. 2010). Pteromalid parasitoid that feeds on houseflies at the pupal stage is used as a more suitable biological control agent of housefly population for decades.

\section{Chemical control}

Many sprays which are pre-hyoid-based insecticides can also suppress the population of housefly population in humans-dwelling areas. It was also observed that houseflies showed resistance to DDT, carbamate, pyrethroid, and organophosphates insecticides. Moreover, resistance against growth regulators like cyromazine and diflubenzuron was also observed, and the use insecticides for control of housefly population in the start is very effective but houseflies may develop readily resistance to persistent because of its insecticides either because of its enzymes that may break down insecticides or of its behavioral adaptations due to which houseflies may avoid insecticides. Moreover, cross-resistance also has been observed like juvenile hormone mimics. There are certain factors which make the use of insecticides less effective like resistance and tolerance of houseflies for insecticide use, increasing costs of insecticides, and toxicity level of insecticide for organisms other than houseflies. Further, it appears hard to discover new insecticides, and the costs of their development are high (Iqbal et al. 2014).

\section{Conclusion}

The common housefly is a mechanical vector of transmission of pathogens including parasites, bacteria, fungi, and viruses. The combination of different methods for control and prevention or eradication of houseflies should be implemented to stop human or animal diseases. In high-risk areas, health education, proper environmental sanitation, and personal hygiene are strongly advocated.

\section{Acknowledgements \\ This study was supported by medical parasitology department in Research Institute of Ophthalmology, Giza, Egypt. \\ Funding \\ Not applicable. \\ Availability of data and materials \\ The author agreed to use data and materials with reference.

\begin{abstract}
Authors' contributions
The author participated in preparing and treating of the experiments and writing of the manuscript. The author read and approved the final manuscript.
\end{abstract}

Ethics approval and consent to participate

Not applicable

Consent for publication

The author gives consent to publish this manuscript in the NRC bulletin.

Competing interests

The author declares that she has no competing interests.

\section{Publisher's Note}

Springer Nature remains neutral with regard to jurisdictional claims in published maps and institutional affiliations. 
Received: 15 March 2019 Accepted: 4 April 2019

Published online: 02 May 2019

\section{References}

Adenusi AA and Adewoga TO (2013a) Prevalence of helminthic ova Human intestinal parasites in non-biting in Shiraz playground and recovering of $E$ coli synanthropic flies in Ogum State, Nigeria. Travel. In this study show that serous measures should be Med. Infect. Dis., 11:181-9. done in this locality as they are of public health

Adenusi AA, and Adewoga TO (2013b) Larvae observed were not harmful to man. The Studies on the potential and public health importance recovered parasites were specific for houseflies and of non-biting synanthropic flies in the mechanical were not also pathogenic to man as previously reported transmission of human enterohelminths. Trans. [28, 29]. In spite of nonpathogenic parasites were R. Soc. Trop. Med. Hyg., 107: 812-8. Recovered in this study it demonstrates the important role

Al-Aredhi HS (2015) Role of house flies (Musca domestica) as vector host for parasitic pathogens in Al-Diwaniya Province / Iraq. 4(4):1961-1965

Awache I, Farouk AA (2016) Bacteria and fungi associated with houseflies collected from cafeteria and food Centres in Sokoto. FUW Trends Sci Technol J 1(1):123-125

Deakpe TE, Manyi MMI, Utume LN (2018) Pathogenic parasites and bacteria associated with the housefly ( Musca domestics) in Makurdi; a fly-infested area in Central Nigeria. J Parasitol 39(1):111-115

El-Sherbini GT and El-Sherbini ET (2011). The role of cockroaches and flies in Mechanical transmission of medical important parasites. Journal of Entomology and Nematology. 3(7):98-104

Hussein AN (2014) Phenotypic and genotypic characteristics of Candida species isolated from some domestic insects in Diwaniya city/ Al-Qadisiya governorate. Wasit J Scie Med 7(1):1-14

lqbal W, Malik MF, Sarwar MK, Azam I, Iram N, Rashda A (2014) Role of housefly ( Musca domestica, Diptera; Muscidae) as a disease vector; a review. J Entomol Zool Stud 2(2):159-163

James EA (2019) The house fly and fowl tapeworm transmission. Kans Acad Sci 30:202-204 Lietze VU, Salem TZ, Prompiboon P, Boucias DG (2010) Tissue tropism of the Musca domestica salivary gland hypertrophy virus. Virus Res 155:20-27

Martin AM (2012) Fisheries Processing: Biotechnological applications. Springer Science \& Business Media. B.V. Canada. ISBN 978-1-4615-5303-8(eBook)

Motazedian MH, Davood M, Golnoush M (2014) The role of Musca domestica as a carrier of parasites in Shiraz, Southern Iran. Acad J Entomol 7(3):84-87

Mwamburi LA, Laing MD, Miller R (2011) Laboratory and field evaluation of formulated Bacillus thuringiensis var. israelensis as a feed additive and using topical applications for control of Musca demestica ( Diptera: Muscidae ) larvae in caged-poultry manure. Environmental Entomology; 40:52-58

Nwangwu UC, Onyido AE, Egbuche CM, Iwueze MO, Ezugbo-Nwobi IK (2013) Parasites Associted with wild-caught houseflies in Awka metropolis. IOSR J Pharm Biol Sci 6(1):12-19

Onyenwe E, Okore OO, Ubiaru PC, Abel C (2016) Housefly-borne helminth parasites of Mouau and its public health implication for the university community. Anim Res Int 13(1):2352-2358

Phoku JZ, Barnard TG, Potgieter N, Dutton MF (2016) Fungal dissemination by housefly ( Musca domestica L) and contamination of food commodities in rural areas of South Africa. Int J Food Microbiol 217:177-181

Sarwar MK, Azam I, Iram N, lqbal W Rashda A, Anwer F et al (2014) Cotton aphid Aphis gossypii L. (Homopetra; Aphididae ); a challenging pest; biology and control strategies: a review. Int J Appl Biol Pharm Technol 5(1):288-294

Tysasmaya T, Wuryastuty H, Wasito W, Sievert K (2016) Avian influenza virus H5N1 remained exist in internal organs of house flies 24 hours post-infection. J Vet Dent 17(2):205-210

Urzua A, Santander R, Echeverria J, Cabezas C, Palacios SM, Rossi Y (2010) Insecticide properties of the essential oils from Haplopappus foliosus and Bahia a Mbrosioides against the housefly, Musca domestica. J Chilean Chem Soc 55:392-395

Yahaya MA, Obed G, Ejimadu LC, James Rugu NU (2016) Microhabitats and pathogens of houseflies (Musca domestica): public health concern. Electron J Biol 12(4):374-380

\section{Submit your manuscript to a SpringerOpen ${ }^{\circ}$ journal and benefit from:}

- Convenient online submission

- Rigorous peer review

- Open access: articles freely available online

- High visibility within the field

- Retaining the copyright to your article

Submit your next manuscript at $\boldsymbol{\nabla}$ springeropen.com 